\title{
Nucleus Accumbens-Associated Protein 2
}

National Cancer Institute

\section{Source}

National Cancer Institute. Nucleus Accumbens-Associated Protein 2. NCI Thesaurus. Code $C 111942$.

Nucleus accumbens-associated protein 2 ( $587 \mathrm{aa}, \sim 63 \mathrm{kDa}$ ) is encoded by the human NACC2 gene. This protein plays a role in the regulation of both cell proliferation and mitosis. 